\title{
Structural characterization and bioactivities of a polysaccharide from the stalk residue of Pleurotus eryngii
}

\author{
Heng-Guang ZHENG ${ }^{1 *}$, Jun-Chen $\mathrm{CHEN}^{1}$, Min-Jie WENG ${ }^{1}$ (D), Ijaz AHMAD ${ }^{2}$, Chun-Quan ZHOU ${ }^{3}$
}

\begin{abstract}
The structural characterization and bioactivities of a polysaccharide from the stalk residue of Pleurotus eryngii were investigated. Firstly the stalk residue of P. eryngii was collected from the top portion of spent mushroom substrate and processed to yield water-soluble polysaccharide. Subsequently this crude polysaccharide was purified by DEAE Sepharose CL-6B ion exchange chromatography and Sepharose CL-6B size-exclusion chromatography. Then its structural features were investigated by gas chromatography (GC), gel permeation chromatography (GPC), methylation analysis, and Fourier Transform Infrared Spectrum (FT-IR). The results showed that it was heteropolysaccharide and mainly composed of glucose (82.4\%). The backbone of P-2a mainly consisted of 1, 3-linked (42.7\%) and 1, 6-linked (35.5\%) glucose residues. Besides, in vitro antioxidant assay showed that P-2a exerted a high scavenging effects on hydroxyl radical and in vitro antitumor assay showed it had a dose-dependent antiproliferative effect against human gastric MGC-803 cancer cells \& human epithelial Hela cancer cells. The findings of this study suggested that the polysaccharide extracted from the stalk residue has the similar structure and bioactivities as that from fruit-body of the mushroom. It could be potentially used as a natural source for the development of health-care food.
\end{abstract}

Keywords:Pleurotus eryngii; stalk residue; polysaccharide; structural characterization; bioactivities.

Practical Application: This study indicated that it is promising to explore the stalk residue of Pleurotus eryngii as an abundant and inexpensive source of functional mushroom polysaccharides.

\section{Introduction}

Mushroom cultivation is a promising cottage industry in China. It supplies delicious and nutritious foods (Zheng et al. 2018). Mushrooms contain appreciable amount of protein and fiber contents. Mushroom cultivation is also beneficial for the ecological cycle of agriculture because the raw materials for raising mushroom are recyclable cereal straw and organic waste or other organic by-products. These huge lignocelluloses biomass wastes can be conversed into human food by means of cropping mushrooms (Zhang et al., 2014). Moreover, mushroom production can provide good income opportunities for families who do not have enough land to produce crops and raise animals (Banasik et al., 2017).

Mushrooms may produce many kinds of bioactive compounds, generally related with mycelial cell wall, that help in boosting the immune capacity to fight against carcinogens (Matloub et al., 2016). However, the rapid growth of mushroom industry also generates large amounts of stalk residue. Especially for the mushroom of Pleurotus eryngii (also called "king oyster mushroom"), a large number of the stalk residue can be collected by cutting off the top portion of spend mushroom composts in bag-logs and weighed as many as $20 \% \sim 30 \%$ biomass of the fruit body (Chen et al., 2013a). Whereas, this stalk residue generally contains some impurities of visible residual compost, for the reason of sanity, it is unable to be consumed directly like the fruit body of the mushroom. In order to get profit from this waste, several attempts were made to extract functional polysaccharides from it. The functionality of these polysaccharides mainly included anti-cancer and antioxidant (Ma et al., 2014; Ma et al., 2016).

Nevertheless, so far to our best knowledge, there is little published information about its linkage feature of monosaccharide as well as the antitumor activities against cancer cells other than A549 human lung cancer cells. Also, it is not clear that whether the polysaccharide extracted from the stalk residue would have the same structure and bioactivities as that from fruit-body (Yan et al., 2019). Therefore, in the present study, we purified the polysaccharide from stalk residue of Pleurotus eryngii, determined the chemical characterization, and evaluated the antitumor and antioxidant activities. In particular, the strain of Pleurotus eryngii that was adopted and preparation of mushroom polysaccharide has been described in detail, so as to keep the consistency with previous literatures and avoid contradictory. The results of this study will be helpful to explore this huge quantity of stalk residue as an inexpensive source of functional mushroom polysaccharide. 


\section{Materials and methods}

\subsection{Materials and chemicals}

Human cancer cell lines of gastric MGC-803 and epithelial Hela were obtained from Cell Bank of Institute of Biochemistry and Cell Biology, Chinese Academy of Sciences (Shanghai, China). DEAE-Sepharose CL-6B and Sepharose CL-6B resins were purchased from Pharmacia Co. (Sweden), while T-series dextran standards (T-500, T-200, T-100, T-50, and T-10) were purchased from Amersham Pharmacia (Uppsala, Sweden). The monosaccharide standards (mannose, galacturonic acid, glucose, galactose, fructose, and arabinose), dimethylsulfoxide (DMSO), bovine serum albumin (BSA), trifluoroaceric acid (TFA), 3-(4, 5-dimethylthiazol-2-yl)-2 and 5-diphenyltetrazoliumbromide (MTT) were purchased from Sigma Chemical Co. (St. Louis, MO, USA). Medium RPMI1640, dimethylsulfoxide (DMSO) and fetal bovine serum (FBS) were purchased from Gibco-BRL (Life Technologies, Inc., USA). Fluorouracil (5-FU), penicillin and streptomycin were purchased from Jiangsu Heng Rui Pharmaceutic Co. (Lianyungang, China). All other chemicals used in experiments were of analytical grade.

\subsection{Carbohydrate and protein contents}

Total carbohydrate contents in polysaccharide were determined by phenol-sulfuric acid colorimetric method, using glucose as standard (Dubois et al., 1956). Total uronic acid content was assayed by $m$-hydroxydiphenyl method, using galacturonic acid as standard (Blumenkrantz \& Asboe-Hansen, 1973). Protein content in the polysaccharide was measured according to the method of Bradford (1976), using BSA as standard.

\subsection{Microorganism and culturing}

P. eryngii strain (No.6) was purchased from Sanming Sanzhen Biological Science and Technology Co. Ltd. of China. Its culturing was accomplished by a mushroom producer, Fujian Shunwei Food Co. Ltd., China. The culture medium was prepared by mixing cottonseed hulls, sawdust and wheat bran at the ratio of $2: 1: 1$ with $0.2 \%$ calcium carbonate. The compost media was filled in $\varnothing 17.5 \mathrm{~cm} \times 32.5 \mathrm{~cm}$ size polypropylene bags, autoclaved, cooled, inoculated, and kept in the darkness until the mycelia had completely penetrated into the bottom of the substrate. At the end of the incubation period, upper portion of the spawned mushroom bags were cut open to facilitate the mushroom fructification. Frequent but light irrigation was provided to maintain an ideal humid atmosphere for the mushroom development. The temperature, relative humidity and light of the culture house were maintained at $13 \sim 22{ }^{\circ} \mathrm{C}, 70 \% \sim 85 \%$ and about 180 250 lux, respectively. Mushrooms were harvested when the mushroom cap surfaces were flat to slightly up-rolled at the cap margins. Then, the stalk residue was cut off from the top portion of the spend culture medium, washed and removed off the impurities of visible residual compost by hands. The cleaned stalk residue was dried $\left(60^{\circ} \mathrm{C}\right)$, ground, sieved through a No. 200 mesh and ready for further use.

\subsection{Isolation}

$10 \mathrm{~g}$ powder of $P$. eryngii stalk residue was firstly refluxed with $85 \%$ ethanol at room temperature for $4 \mathrm{~h}$ to remove lipophilic compounds (Ma et al., 2014). After filtration, the residues were dried in air, and then extracted with distilled water under an optimized condition (ratio of water to material, $25 \mathrm{~mL}$ : $1 \mathrm{~g}$, leaching temperature $60^{\circ} \mathrm{C}$, leaching time $60 \mathrm{~min}$ ). The whole extract solution was filtered and centrifuged at $5000 \times \mathrm{g}$ for $10 \mathrm{~min}$, and the supernatant was concentrated into one-tenth of the original volume by evaporation at $45^{\circ} \mathrm{C}$. After the supernatant was deproteinized with Sevag reagent (chloroform: butanol, 4:1), 3 -fold volume anhydrous ethanol was added to precipitate the crude polysaccharide for $12 \mathrm{~h}$ at $4^{\circ} \mathrm{C}$. Following centrifugation at $5000 \times \mathrm{g}$ for $10 \mathrm{~min}$, the precipitate was washed successively with anhydrous ethanol and acetone, dialyzed against deionized water and lyophilized as the crude polysaccharide. The yield of crude polysaccharides was around $0.5 \mathrm{~g}$.

\subsection{Purification}

The crude polysaccharide (150 mg) was dissolved in $100 \mathrm{~mL}$ distilled water and micro-filtrated through $0.45 \mu \mathrm{m}$ membrane. The permeation solution was subjected to a DEAE-Sepharose CL-6B $(\varnothing 3.6 \mathrm{~cm} \times 20 \mathrm{~cm})$, and eluted with $500 \mathrm{~mL}$ distilled water and subsequently with $500 \mathrm{~mL} 0.1 \mathrm{M} \mathrm{NaCl}$ at a flow rate of $1 \mathrm{~mL} / \mathrm{min}$. Different fractions $(10 \mathrm{~mL} /$ tube $)$ namely P-1, and P-2 were collected according to the total carbohydrate content quantified by phenol-sulfuric acid method using an automatic fraction collector. After dialysis, concentrated and lyophilized, P-2 was further purified with a Sepharose CL-6B column $(\varnothing 3.6 \mathrm{~cm} \times 90 \mathrm{~cm})$ eluted with distilled water at a flowrate of $0.5 \mathrm{~mL} / \mathrm{min}$ to yield two main final fractions (10 mL/tube). Fractions of the first peak were collected, dialyzed, freeze dried and named as $\mathrm{P}-2 \mathrm{a}(68 \mathrm{mg})$ for further investigation of the structure characterization and antitumor activity.

\subsection{Homogeneity and molecular weight}

The homogeneity and molecular weight of P-2a were determined by gel permeation chromatography (GPC) on a Waters 2695 HPLC system equipped with a TSK-gel PWXL G4000 column, eluted with distilled water at a flow rate of $0.5 \mathrm{~mL} / \mathrm{min}$ and detected by a refractive index detector (RID). $10 \mu \mathrm{L}$ of sample solution $(1.0 \mathrm{mg} / \mathrm{mL})$ was injected in each run. The column was kept at $30.0 \pm 0.1{ }^{\circ} \mathrm{C}$. The standard curve of molecular weight was obtained with the T-series Dextrans standards (1000, 5000, 12,000, 80,000, 150,000, 270,000 and 670,000 Da). The molecular weight of P-2a was estimated with reference to the calibration curve made above (Zhang et al., 2013).

\subsection{Monosaccharide composition analysis}

P-2a (2 mg) and standard monosaccharides were hydrolyzed with $2 \mathrm{M}$ trifluoroacetic acid (TFA, $4 \mathrm{~mL}$ ) at $110^{\circ} \mathrm{C}$ for $2 \mathrm{~h}$. The excess TFA was removed by vacuum evaporation with ethanol. The hydrolyzed mixtures were reduced with $\mathrm{NaBH}_{4}(20 \mathrm{mg})$ and acetylated with acetic anhydride. The acetylated derivatives of samples were analyzed by gas chromatography (GC) using an Agilent $7890 \mathrm{~N}$ instrument equipped with an HP-5 capillary column $(30 \mathrm{~m} \times 0.32 \mathrm{~mm} \times 0.25 \mu \mathrm{m})$ and a flame-ionization detector (FID). The temperature program consisted of $120-240^{\circ} \mathrm{C}$ at $10^{\circ} \mathrm{C} / \mathrm{min}$ and then held at $240{ }^{\circ} \mathrm{C}$ for $6.5 \mathrm{~min}$. The heater temperatures 
of the injector and detector were both at $250{ }^{\circ} \mathrm{C}$. Nitrogen was used as carrier gas (Albersheim et al., 1967).

\subsection{Methylation analysis}

In order to determine the glycosyl linkages, P-2a (2 mg) was methylated twice according to the methods of Ciucanu \& Kerek (1984). Briefly, the vacuum-dried P-2a was dissolved in DMSO $(1.5 \mathrm{~mL})$ and then methylated with a saturated $\mathrm{NaOH} / \mathrm{DMSO}$ solution $(1.5 \mathrm{~mL})$ and $\mathrm{CH}_{3} \mathrm{I}(1 \mathrm{~mL})$. The reaction mixture was extracted with $\mathrm{CHCl}_{3}$, and the solvent was then removed by evaporation. Complete methylation was confirmed by the disappearance of the $\mathrm{OH}$ band $\left(3200 \sim 3700 \mathrm{~cm}^{-1}\right)$ in the IR spectrum. The permethylated polysaccharide was hydrolyzed by treatment with $\mathrm{HCO}_{2} \mathrm{H}(88 \%, 3 \mathrm{~mL})$ at $100{ }^{\circ} \mathrm{C}$ for $3 \mathrm{~h}$, evaporated to dryness and further hydrolyzed with $2 \mathrm{M}$ TFA $(4 \mathrm{~mL})$ at $100{ }^{\circ} \mathrm{C}$ for $6 \mathrm{~h}$. The partially methylated sugar in the hydrolysate was reacted with $\mathrm{NaBH}_{4}$ and acetylated with $\mathrm{AC}_{2} \mathrm{O}$. The resulting mixture of methylated alditol acetates was analyzed for the glycosidic linkage by a gas chromatography/mass spectrometer (GCMS-QP 2010, Shimadzu, Kyoto, Japan).

\subsection{Fourier Transform Infrared (FT-IR) spectroscopy}

Spectroscopy FT-IR spectra was assayed with $\mathrm{KBr}$ pellets using a spectrophotometer (model VERTEX 70, Bruker Corporation, Germany) over the wavelength range $400 \sim 4000 \mathrm{~cm}^{-1}$.

\subsection{Scavenging hydroxyl radical activity assay}

The scavenging capacity of polysaccharides extract on $\mathrm{OH}^{-}$was evaluated according to the reaction of sodium salicylate and residual hydroxyl radical. $\mathrm{OH}^{-}$scavenging assay was performed according to the procedure (Winterbourn \& Button, 1984) with a few modifications. Hydroxyl radicals were generated by Fenton reaction in the system of $\mathrm{FeSO}_{4}$ and $\mathrm{H}_{2} \mathrm{O}_{2}$. The reaction mixture consisted of $0.5 \mathrm{~mL} \mathrm{FeSO}_{4}(8 \mathrm{mM}), 0.8 \mathrm{~mL} \mathrm{H}_{2} \mathrm{O}_{2}(6 \mathrm{mM}), 0.5 \mathrm{~mL}$ distilled water, $1.0 \mathrm{~mL}$ polysaccharides extract (different concentrations) and $0.2 \mathrm{~mL}$ sodium salicylate $(20 \mathrm{mM})$. The total mixture $(3.0 \mathrm{~mL})$ was incubated at $37^{\circ} \mathrm{C}$ for $1 \mathrm{~h}$ and then the absorbance of the mixture was recorded at $562 \mathrm{~nm}$. The scavenging activity was calculated using the following equation: scavenging (or inhibition) rate $(\%)=\left[1-\left(\mathrm{A}_{1}-\mathrm{A}_{2}\right) / \mathrm{A}_{0}\right] \times 100$, where $\mathrm{A}_{0}$ is the absorbance of the control (without sample), $A_{1}$ the absorbance of the sample and $A_{2}$ the absorbance without sodium salicylate.

\subsection{Antitumor activity in vitro assay}

The growth inhibitory activities of samples against Human cancer cell lines of gastric MGC-803 and epithelial Hela were investigated using colorimetric MTT assay (Mosmann, 1983). The cells were cultured in RPMI1640 medium supplemented with $10 \%$ fetal bovine serum and 100 unit/mL penicillin streptomycin solutions at $37^{\circ} \mathrm{C}$ in a $5 \% \mathrm{CO}_{2}$ environment. The cells $\left(1.0 \times 10^{4}\right.$ cells/well $)$ and samples $(100,500,1000 \mathrm{ug} / \mathrm{mL})$ were incubated for $72 \mathrm{~h}$, followed by addition of MTT solution and further incubation for $4 \mathrm{~h}$. The resulting formazan crystals were dissolved in dimethyl sulfoxide and their absorbances were measured by ELISA (ELx800UV, Bio-Tek Instrument Inc., Windoski, VT, USA) at $540 \mathrm{~nm}$. 5-Fluorouracil (5-FU, $100 \mathrm{ug} / \mathrm{mL}$ ) was used as a positive control. The inhibition rate was calculated according to the formula below: Growth inhibition rate $(\%)=(1$-Absorbance of experimental group/Absorbance of blank control group) $\times 100$.

\subsection{Statistical analysis}

Statistical analyses of the data were performed by using the Statistical Package for the Social Sciences (SPSS) software (Version 20.0, SPSS Inc., Chicago, IL). The results obtained were based on mean of three replicates \pm standard deviation (SD). Significant differences obtained in the mean values were determined using t-test with level of significance considered at $\mathrm{P}<0.05$.

\section{Results and discussion}

\subsection{Purification of polysaccharide}

Two major elution peaks named as P-1 and P-2 were separated by DEAE-Sepharose CL-6B anion-exchange chromatography according to their ionic-binding capacity (Figure 1A). The first peak (P-1) mainly contained a neutral polysaccharide as it was gained by elution with distilled water, while the second peak (P-2) was mainly ascribed to the acidic polysaccharide because it was collected by elution with $0.1 \mathrm{~mol} / \mathrm{L} \mathrm{NaCl}$ solutions. The weight ratio of P-1 and P-2 was around 3:7. Subsequently, P-2 was loaded to gel filtration column of Sepharose CL-6B and its components were separated according to the difference in molecule sizes (Figure 1B). The high-molecular-weight component of P-2a was purified, while the low-molecular-weight components of proteins and polysaccharides were removed. The elution profile of $\mathrm{P}-2 \mathrm{a}$ in this study was basically in consistent with the previous report of Ma et al. (2014).

\subsection{Molecular weight and monosaccharide composition}

The average molecular weight of P-2a was calculated as $410 \mathrm{kDa}$ by GPC according to the calibration curve with standard dextrans and glucose (Table 1). The GPC profile of P-2a (Figure 2) was a single and symmetrically sharp peak, revealing that $\mathrm{P}-2 \mathrm{a}$ was a homogeneous polysaccharide. GC analysis showed that P-2a mainly composed of five kinds of monosaccharides and a galacturonic acid. Glucose was the predominant monosaccharide (82.4\%), which was in agreement with the most of the previous reports (Ma et al., 2014; Zhang et al., 2013, 2016, 2018; Ren et al., 2016; Li \& Shah, 2016), but was different from the results of Yang et al. (2013) who reported that it was composed of arabinose, mannose and galactose in a molar ratio of 1.2:2.3:6.2. The vast differences in these experimental results of monosaccharide composition might be attributed to the genetic properties of polysaccharides. As the polysaccharides are the secondary metabolites present in fungal species, its genetic stability might be far lower than that of proteins (Mei et al., 2015). Consequently, composition of the mushroom polysaccharide may be varied due to the influence of different culturing strains, different culturing methods or even different harvest date etc (Synytsya \& Novák, 2013). 
Table 1. Molecular weight and monosaccharide composition of $\mathrm{P}_{2}$-a.

\begin{tabular}{|c|c|c|c|c|c|c|c|c|c|c|}
\hline \multirow{2}{*}{ Sample } & \multirow{2}{*}{$\mathrm{Mw}(\mathrm{Da})$} & \multirow{2}{*}{$\begin{array}{c}\text { Total } \\
\text { Sugar } \\
(\%)\end{array}$} & \multirow{2}{*}{$\begin{array}{c}\text { Protein } \\
(\%)\end{array}$} & \multirow{2}{*}{$\begin{array}{c}\text { Uronic } \\
\text { acid }\end{array}$} & \multicolumn{6}{|c|}{ Molar ratios of monosaccharides (\%) } \\
\hline & & & & & Ara & Fuc & Gal & Glc & Man & GalA \\
\hline P2-a. & 410,000 & 75.1 & 22.8 & 2.8 & 0.96 & 1.12 & 1.73 & 82.40 & 9.85 & 3.93 \\
\hline
\end{tabular}

Table 2. GC-MS data for methlytion analysis of P2-a.

\begin{tabular}{lccc}
\hline \multicolumn{1}{c}{ Methylated sugar } & Ret. time $^{\mathrm{a}}(\mathrm{min})$ & ${\text { Mole percent }(\%)^{\mathrm{b}}}$ & Linkage type \\
\hline 2, 3, 4, 6- $\mathrm{Me}_{4}-\mathrm{Man} p$ & 6.54 & 3.8 & $1-$ \\
2, 3, 4, - $\mathrm{Me}_{3}-\mathrm{Glc} p$ & 7.59 & 35.5 & $1,6-$ \\
2, 3, 4- $\mathrm{Me}_{3}-\mathrm{Gal} p$ & 7.90 & 6.3 & $1,6-$ \\
1, 3, 6- $\mathrm{Me}_{3}-\mathrm{Man} p$ & 8.28 & 4.1 & $2,4-$ \\
2, 4, 6- $\mathrm{Me}_{3}-\mathrm{Glc} p$ & 8.75 & 42.7 & $1,3-$ \\
2, 4- $\mathrm{Me}_{2}-\mathrm{Man} p$ & 9.88 & 6.7 & $1,3,6-$ \\
\hline
\end{tabular}

${ }^{a}$ Based on derived O-methylalditol acetates; ${ }^{\mathrm{b}}$ Derived from the GC peak areas of O-methylalditol acetates.

\subsection{FT-IR spectroscopy}

As shown in Figure 3, P-2a appeared absorption bands at 3000 3500 $\mathrm{cm}^{-1}$ (hydroxyl stretching vibration), $2920 \mathrm{~cm}^{-1}$ (C-H stretching vibration), $1550 \sim 1800 \mathrm{~cm}^{-1}$ (C=O vibration), $1300 \sim 1480 \mathrm{~cm}^{-1}$ (carboxyl groups), and $950 \sim 1200 \mathrm{~cm}^{-1}$ (pyranose ring) (Synytsya et al., 2009), indicating the typical absorptions of polysaccharides (Zhang et al., 2018). A strong absorption peak at around $1636 \mathrm{~cm}^{-1}$ was reported to be caused by $\beta$-glycosidic bonds and hydrogen bond absorptions associated with trace water (Liu et al., 2016). However, the spectral range $820 \sim 950 \mathrm{~cm}^{-1}$ was the anomeric region because the vibration bands for $\alpha$ - and $\beta$-configuration were well separated in this region (Xu et al., 2009). The characteristic absorption band at $827 \mathrm{~cm}^{-1}$ and $920 \mathrm{~cm}^{-1}$ suggested a small amount of $\alpha$-configurations maybe simultaneously existing with $\beta$-configuration in $\mathrm{P}$ - $2 \mathrm{a}$, which was also reported by other researchers (Li \& Shah, 2016; Chen et al., 2013b). In addition, typical $\mathrm{N}-\mathrm{H}$ vibration at about $3400 \mathrm{~cm}^{-1}$ might be overlapped by $\mathrm{OH}$ stretch vibration at $3000 \sim 3500 \mathrm{~cm}^{-1}$. The absorption of uronic acid that was previously reported at the region of $1720 \mathrm{~cm}^{-1}$ (Wang et al., 2010) and - $-\mathrm{NH}_{2}$ stretching vibration at $1618.25 \mathrm{~cm}^{-1}$ (Černá et al., 2003) might be overlapped by the strong absorption peak of $\beta$-glycosidic bonds at $1636 \mathrm{~cm}^{-1}$. Thus, the IR spectrum of $\mathrm{P}-2 \mathrm{a}$ and the above composition analysis suggested that $\mathrm{P}-2 \mathrm{a}$ was mainly composed of a $\beta$-type glycosidic bond-linked glucopyranose.

\subsection{Methylation analysis}

As summarised in Table 2, methylation analysis by GC-MS showed that the backbone structure of P-2a mainly consisted of 1, 3-linked (42.7\%) and 1, 6-linked (35.5\%) glucose residues. The branching linkages in P-2a mainly existed as 1, 3, 6-linked $\operatorname{Man} p(6.7 \%)$. The terminal positions of the polysaccharide molecules were Man residues (3.8\%). The $\mathrm{m} / \mathrm{z}$ of 43 and 117 of acetyl ion were detected as glycosyl residues (Pan et al., 2012). Besides, the assay result of linkage features of $\mathrm{P}-2 \mathrm{a}$ in this study was basically in agree with Chen et al. (2013b), Ren et al. (2016), Synytsya et al. (2009) and Carbonero et al. (2006), who reported
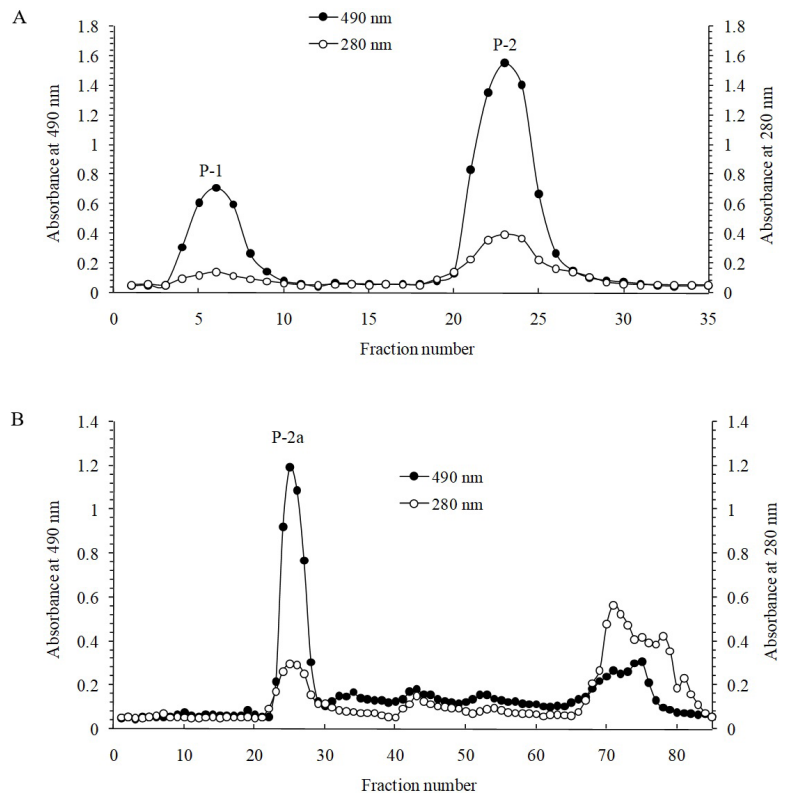

Figure 1. Fractionation of the isolated polysaccharide P-2a from P. eryngii with DEAE Sepharose CL-6B anion-exchange chromatography (A) and Sepharose CL-6B gel filtration chromatography (B).

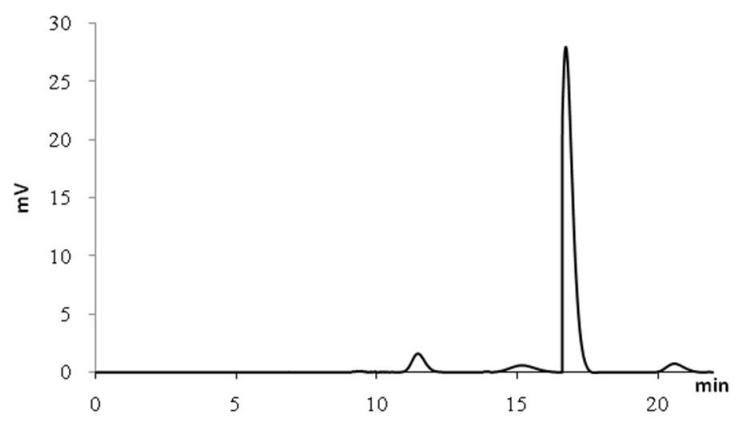

Figure 2. GPC chromatogram of the isolated polysaccharide P-2a with refractive index detector.

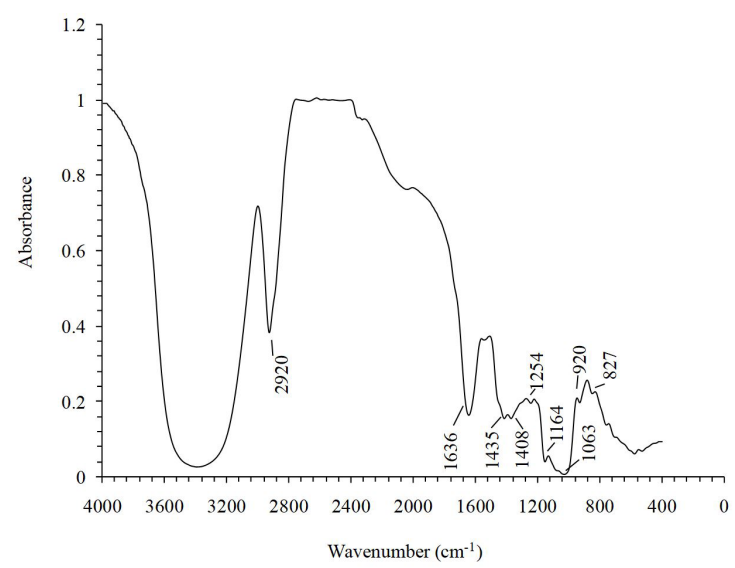

Figure 3. FT-IR spectra of polysaccharide P2-a from Pleurotus eryngii. 
that the polysaccharide of Pleurotus eryngii mainly contained $(1 \rightarrow 3)$ and $(1 \rightarrow 6)$-linked $\beta$-glucan. However, the assay result in this study is inconsistent with Yang et al. (2013) and Liu et al. (2015) who reported that the polysaccharide of Pleurotus eryngii mainly contained $(1 \rightarrow 6)$-linked-Galp and $(1 \rightarrow 4)$-linked $\beta$-glucan respectively. Just like the great difference on the forgoing analysis of monosaccharide composition, the diverse linkage feature here also showed the complexity of the polysaccharide structure. In other words, the structure of isolated polysaccharides may be totally different, even though they were extracted from the same kind of mushroom. In addition, the reported linkage features for P-2a in this study was needed to be further confirmed by other analysis methods, such as periodate oxidation, Smith degradation and NMR characterization. In a word, since structure of the polysaccharides is strongly related to its antitumor activity, the above analysis of the polysaccharide structure will help to elucidate its structure-activity relationship, clarify the relevant mechanism and promote related application.

\subsection{Scavenging activity on hydroxyl radicals}

It could be seen from Figure 4 that P-2a exhibited saturated hydroxyl radical scavenging activity of about $90 \%$ in the tested concentration range $(2 \sim 5 \mathrm{mg} / \mathrm{mL})$. The scavenging potency of ascorbic acid on hydroxyl radicals was only around $60 \%$ at a dose of $5 \mathrm{mg} / \mathrm{mL}$, indicating that P-2a showed similar strong scavenging activity for hydroxyl radicals when the dose was beyond $2 \mathrm{mg} / \mathrm{mL}$. Hydroxyl radical is the most reactive dangerous free radical among reactive oxygen species (ROS). It can be due to the Fenton reaction in biological cells, easily cross cell membranes, severely damage adjacent macromolecules, and cause disease. Accordingly, scavenging hydroxyl radical is important for the protection of the living system. The different activity of scavenging hydroxyl radical between polysaccharides may be caused by the amount of protein in crude polysaccharide samples, because hydroxyl radicals can reduce disulfide bonds in proteins and also converse amino acid of Phenylalanine (Phe) to Tyrosine (Tyr). This opinion was also supported by other researchers who reported that lentinan and schizophyllan, which contained little amount of protein in the polysaccharide samples, exhibited nearly no scavenging activities of hydroxyl radicals (Liu et al., 1997).

\subsection{In vitro tumor inhibitory activity}

Most of mushroom polysaccharide was found to exert the antitumor activities, and two relative mechanisms including Immuno-enhancing and direct tumor inhibition have been proposed (Meng et al., 2016). In this study, the antitumor activities (in vitro) of polysaccharide P-2a were assessed by evaluation of anti-proliferative effects on two different types of cancer cells. Moderate antitumor activity against human cancer cells of gastric MGC-803 and epithelial Hela were shown for P-2a (Figure 5). The inhibitory activities of $\mathrm{P}-2 \mathrm{a}$ for cells proliferation of MGC-803 and Hela increased significantly $(\mathrm{P}<0.05)$ with increasing concentration, which showed a dose-dependent effect within the concentration ranges tested.

Almost all of the chemotherapy drugs currently in the market can cause serious side effects (Dickens \& Ahmed, 2018).

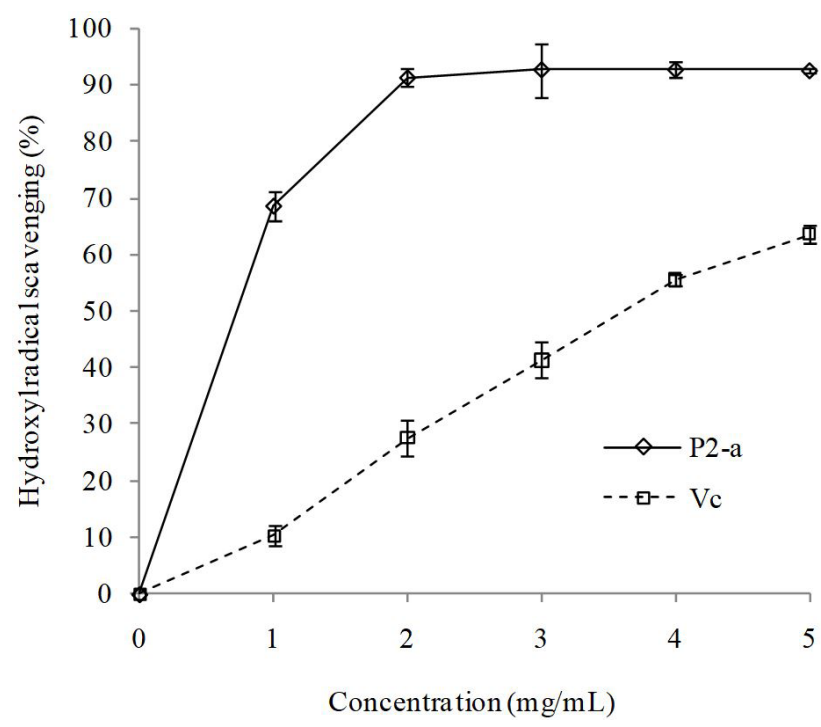

Figure 4. Scavenging activity of polysaccharide to hydroxyl radical.
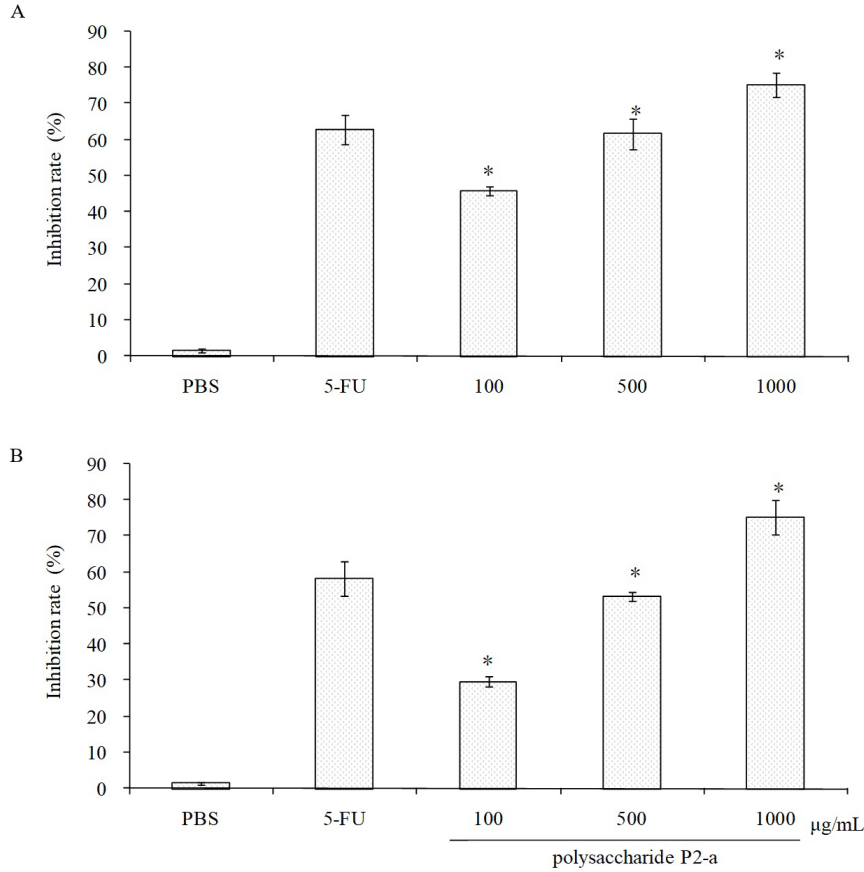

Figure 5. Cancer cell growth inhibition effects of polysaccharide P-2a from P. eryngii against human cancer cells of gastric MGC-803 (A) and epithelial Hela (B). ${ }^{\star}$ Significantly different from native at same concentration of each derivative, $\mathrm{p}<0.05$.

Although 5-FU is one of the most efficacious chemotherapy drugs for cancer treatment. However, continual administration of 5-FU is not always feasible, as it kills many human body-friendly cells while killing tumor cells (Zheng et al., 2019). Thus discovery of new safe compound, capable of antitumor function, has become an important goal of research in the biomedical sciences. Hence, the polysaccharide P-2a in this study may be a potential substitute for 5-FU as remedies and prevention agents for cancer without side-effects. Additionally, the linkage features of monosaccharide 
in P-2a were in agreement with the view of Singdevsachan et al. (2016), who stated that the $\beta-(1-3)$-D-glucan played vital role in antitumor activity.

So far, the anti-proliferative effect of polysaccharides towards tumor lines in vitro remains unclear. Some researchers believed that incubation of polysaccharides together with tumor cells could change the expression of signals within tumor cells. That would arrest the cell cycle and generate apoptosis, which explains the in vitro anti-proliferative effect of polysaccharides (Wang et al., 2018a). Particularly, $\beta$-glucans can induce biological responses by binding to immune receptors and the polysaccharides from the mycelia of mushrooms are mainly protein-containing glucans (Wang et al., $2018 b$ ). The diverse ability of antitumor for polysaccharides was reported to be mainly due to their chemical composition, configuration, and physical properties, etc (Meng et al., 2016). Despite the antitumor activity of mushroom polysaccharides like P-2a in this study has been explored extensively, and the results appeared to be promising, more in-depth investigation is still required, because in most cases the antitumor activities of polysaccharides were tested simply by using cancer cells or tumor-transplanted mouse models without clinical trials (Singdevsachan et al., 2016). In addition, the mass extraction and purification of polysaccharides remained an obstacle for its development as therapeutics (Zhao et al., 2018). Nevertheless, the growing interest in the waste resources from mushroom industry will lead to the wide applications of mushroom polysaccharides in the fields of medicine and food in the future.

\section{Conclusions}

In this study, an antitumor polysaccharide (P-2a) was extracted, purified and identified in order to utilize the abundant resource of stalk residue that was cut off from the top portion of spend mushroom composts of $P$. eryngii. The result indicated that P-2a has an average molecular weight of $410 \mathrm{kDa}$ and was mainly composed of glucose residues (82.4\%). The $\alpha$ - and $\beta$-configurations of glucose residues may simultaneously exist in P-2a. The backbone of P-2a mainly consisted of 1, 3-linked (42.7\%) and 1, 6-linked (35.5\%) glucose residues. The antioxidant assay (in vitro) showed that $\mathrm{P}-2 \mathrm{a}$ had high scavenging effects on hydroxyl radical. Also, the antitumor assay (in vitro) indicated that P-2a possessed antitumor activity against the growth of human cancer cells of gastric MGC-803 and epithelial Hela. The polysaccharide extracted from the stalk residue has the similar structure and bioactivities as that from fruit-body. It seems there is a great potential for exploiting the polysaccharide in formulating food that will improve human health. However, more studies should be performed, especially for the human (clinical) studies on the efficacy of such food products that are needed to establish a health claim. Also, low-cost production of polysaccharides in industrial scale should be further investigated, as it will accelerate the commercial production of mushroom polysaccharides for cancer therapy.

\section{Acknowledgements}

The authors gratefully acknowledge the financial supports by the Chinese Fujian Provincial Special Fund for Agro-scientific Research in the Public Interest (No. 2017R1014-1).

\section{References}

Albersheim, P., Nevins, D. J., English, P. D., \& Karr, A. (1967). A method for the analysis of sugars in plant cell-wall polysaccharides by gasliquid chromatography. Carbohydrate Research, 5(3), 340-345. http:// dx.doi.org/10.1016/S0008-6215(00)80510-8.

Banasik, A., Kanellopoulos, A., Claassen, G. D. H., Bloemhof-Ruwaard, J. M., \& Van Der Vorst, J. (2017). Closing loops in agricultural supply chains using multi-objective optimization: a case study of an industrial mushroom supply chain. International Journal of Production Economics, 183, 409-420. http://dx.doi.org/10.1016/j.ijpe.2016.08.012.

Blumenkrantz, N., \& Asboe-Hansen, G. (1973). New method for quantitative determination of uronic acids. Analytical Biochemistry, 54(2), 484-489. http://dx.doi.org/10.1016/0003-2697(73)90377-1. PMid:4269305.

Bradford, M. M. (1976). A rapid and sensitive method for the quantitation of microgram quantities of protein utilizing the principle of protein binding. Analytical Biochemistry, 72(1-2), 248-254. http://dx.doi. org/10.1016/0003-2697(76)90527-3. PMid:942051.

Carbonero, E. R., Gracher, A. H. P., Smiderle, F. R., Rosado, F. R., Sassaki, G. L., Gorin, P. A. J., \& Iacomini, M. (2006). A $\beta$-glucan from the fruit bodies of edible mushrooms Pleurotus eryngii and Pleurotus ostreatoroseus. Carbohydrate Polymers, 66(2), 252-257. http://dx.doi.org/10.1016/j.carbpol.2006.03.009.

Černá, M., Barros, A. S., Nunes, A., Rocha, S. M., Delgadillo, I., Čopíková, J., \& Coimbra, M. A. (2003). Use of FT-IR spectroscopy as a tool for the analysis of polysaccharide food additives. Carbohydrate Polymers, 51(4), 383-389. http://dx.doi.org/10.1016/S0144-8617(02)00259-X.

Chen, H. B., Chen, C. I., Chen, M. J., Lin, C. C., Kan, S. C., Zang, C. Z., Yeh, C. W., Shieh, C. J., \& Liu, Y. C. (2013a). The use of mushroom hydrolysate from waste bag-log as the nitrogen source to mycelium biomass and exopolysaccharide production in Pleurotus eryngii cultivation. Journal of the Taiwan Institute of Chemical Engineers, 44(2), 163-168. http://dx.doi.org/10.1016/j.jtice.2012.11.006.

Chen, J. J., Yong, Y. Y., Xing, M. C., Gu, Y. F., Zhang, Z., Zhang, S. Z., \& Lu, L. (2013b). Characterization of polysaccharides with marked inhibitory effect on lipid accumulation in Pleurotus eryngii. Carbohydrate Polymers, 97(2), 604-613. http://dx.doi.org/10.1016/j. carbpol.2013.05.028. PMid:23911491.

Ciucanu, I., \& Kerek, F. (1984). A simple and rapid method for the permethylation of carbohydrates. Carbohydrate Research, 131(2), 209-217. http://dx.doi.org/10.1016/0008-6215(84)85242-8.

Dickens, E., \& Ahmed, S. (2018). Principles of cancer treatment by chemotherapy. Surgery, 36, 134-138.

Dubois, M., Gilles, K. A., Hamilton, J. K., Rebers, P. A., \& Smith, F. (1956). Colorimetric method for determination of sugars and related substances. Analytical Chemistry, 28(3), 350-356. http://dx.doi. org/10.1021/ac60111a017.

Li, S. Q., \& Shah, N. P. (2016). Characterization, antioxidative and bifidogenic effects of polysaccharides from Pleurotus eryngii after heat treatments. Food Chemistry, 197(Pt A), 240-249. http://dx.doi. org/10.1016/j.foodchem.2015.10.113. PMid:26616946.

Liu, F., Ooi, V. E. C., \& Chang, S. T. (1997). Free radical scavenging activities of mushroom polysaccharide extracts. Life Sciences, 60(10), 763-771. http://dx.doi.org/10.1016/S0024-3205(97)000040. PMid:9064481.

Liu, X., Wang, L., Zhang, C., Wang, H., Zhang, X., \& Li, Y. (2015). Structure characterization and antitumor activity of a polysaccharide from the alkaline extract of king oyster mushroom. Carbohydrate Polymers, 118, 101-106. http://dx.doi.org/10.1016/j.carbpol.2014.10.058. PMid:25542113.

Liu, Y. T., Chen, D., You, Y. X., Zeng, S. Q., Hu, Y., Duan, X. Y., Liu, A. P., Chen, H., Hu, X. J., Chen, S. J., Li, C., \& Chen, D. W. 
(2016). Structural characterization and antidiabetic activity of aglucopyranose-rich heteropolysaccharide from Catathelasma ventricosum. Carbohydrate Polymers, 149, 399-407. http://dx.doi. org/10.1016/j.carbpol.2016.04.106. PMid:27261764.

Ma, G. X., Yang, W. J., Mariga, A. F., Fang, Y., Ma, N., Pei, F., \& Hu, Q. H. (2014). Purification, characterization and antitumor activity of polysaccharides from Pleurotus eryngii residue. Carbohydrate Polymers, 114, 297-305. http://dx.doi.org/10.1016/j.carbpol.2014.07.069. PMid:25263894.

Ma, G., Yang, W., Fang, Y., Ma, N., Pei, F., Zhao, L., \& Hu, Q. (2016). Antioxidant and cytotoxicites of Pleurotus eryngii residue polysaccharides obtained by ultrafiltration. Lebensmittel-Wissenschaft + Technologie, 73, 108-116. http://dx.doi.org/10.1016/j.lwt.2016.05.049.

Matloub, A. A., Aglan, H. A., Mohamed El Souda, S. S., Aboutabl, M. E., Maghraby, A. S., \& Ahmed, H. H. (2016). Influence of bioactive sulfated polysaccharide-protein complexes on hepatocarcinogenesis, angiogenesis and immunomodulatory activities. Asian Pacific Journal of Tropical Medicine, 9(12), 1200-1211. http://dx.doi.org/10.1016/j. apjtm.2016.11.004. PMid:27955748.

Mei, Y. X., Zhu, H., Hu, Q. M., Liu, Y. Y., Zhao, S. M., Peng, N., \& Liang, Y. X. (2015). A novel polysaccharide from mycelia of cultured Phellinus linteus displays antitumor activity through apoptosis. Carbohydrate Polymers, 124, 90-97. http://dx.doi.org/10.1016/j. carbpol.2015.02.009. PMid:25839798.

Meng, X., Liang, H. B., \& Luo, L. X. (2016). Antitumor polysaccharides from mushrooms: a review on the structural characteristics, antitumor mechanisms and immunomodulating activities. Carbohydrate Research, 424, 30-41. http://dx.doi.org/10.1016/j.carres.2016.02.008. PMid:26974354.

Mosmann, T. (1983). Rapid colorimetric assay for cellular growth and survival: Application to proliferation and cytotoxicity assay. Journal of Immunological Methods, 63(1-2), 55-63. http://dx.doi. org/10.1016/0022-1759(83)90303-4. PMid:6606682.

Pan, D., Wang, L. Q., Chen, C. H., Teng, B. S., Wang, C. D., Xu, Z. X., Hu, B. W., \& Zhou, P. (2012). Structure characterization of a novel neutral polysaccharide isolated from Ganoderma lucidum fruiting bodies. Food Chemistry, 135(3), 1097-1103. http://dx.doi. org/10.1016/j.foodchem.2012.05.071. PMid:22953830.

Ren, D. Y., Wang, N., Guo, J. J., Yuan, L., \& Yang, X. B. (2016). Chemical characterization of Pleurotus eryngii polysaccharide and its tumorinhibitory effects against human hepatoblastoma HepG-2 cells. Carbohydrate Polymers, 138, 123-133. http://dx.doi.org/10.1016/j. carbpol.2015.11.051. PMid:26794745.

Singdevsachan, S. K., Auroshree, P., Mishra, J., Baliyarsingh, B., Tayung, K., \& Thatoi, H. (2016). Mushroom polysaccharides as potential prebiotics with their antitumor and immunomodulating properties: A review. Bioactive Carbohydrates and Dietary Fibre, 7(1), 1-14. http://dx.doi.org/10.1016/j.bcdf.2015.11.001.

Synytsya, A., \& Novák, M. (2013). Structural diversity of fungal glucans. Carbohydrate Polymers, 92(1), 792-809. http://dx.doi.org/10.1016/j. carbpol.2012.09.077. PMid:23218369.

Synytsya, A., Míčková, K., Synytsya, A., Jablonský, I., Spěváček, J., Erban, V., Kováríková, E., \& Čopíková, J. (2009). Glucans from fruit bodies of cultivated mushrooms Pleurotus ostreatus and Pleurotus eryngii: Structure and potential prebiotic activity. Carbohydrate Polymers, 76(4), 548-556. http://dx.doi.org/10.1016/j.carbpol.2008.11.021.

Wang, J. H., Zha, X. Q., Luo, J. P., \& Yang, X. F. (2010). An acetylated galactomannoglucan from the stems of Dendrobium nobile Lindl. Carbohydrate Research, 345(8), 1023-1027. http://dx.doi.org/10.1016/j. carres.2010.03.005. PMid:20382377.
Wang, J. L., Bao, A. B., Meng, X. H., Guo, H. Y., Zhang, Y. D., Zhao, Y. L., Kong, W. B., Liang, J. Y., Yao, J., \& Zhang, J. (2018a). An efficient approach to prepare sulfated polysaccharide and evaluation of anti-tumor activities in vitro. Carbohydrate Polymers, 184, 336-375. http://dx.doi.org/10.1016/j.carbpol.2017.12.065. PMid:29352930.

Wang, Y., Tian, Y., Shao, J., Shu, X., Jia, J., Ren, X., \& Guan, Y. (2018b). Macrophage immunomodulatory activity of the polysaccharide isolated from Collybia radicata mushroom. International Journal of Biological Macromolecules, 108, 300-306. http://dx.doi.org/10.1016/j. ijbiomac.2017.12.025. PMid:29222012.

Winterbourn, C. C., \& Button, H. C. (1984). Hydroxyl radical production from hydrogen peroxide and enzymatically generated paraquat radicals: Catalytic requirements and oxygen dependence. Archives of Biochemistry and Biophysics, 235(1), 116-126. http://dx.doi. org/10.1016/0003-9861(84)90260-1. PMid:6093705.

Xu, X., Chen, P., Wang, Y., \& Zhang, L. (2009). Chain conformation and rheological behavior of an extracellular heteropolysaccharide Erwinia gum in aqueous solution. Carbohydrate Research, 344(1), 113-119. http://dx.doi.org/10.1016/j.carres.2008.10.009. PMid:18977475.

Yan, J., Zhu, L., Qu, Y., Qu, X., Mu, M., Zhang, M., Muneer, G., Zhou, Y., \& Sun, L. (2019). Analyses of active antioxidant polysaccharides from four edible mushrooms. International Journal of Biological Macromolecules, 123, 945-956. http://dx.doi.org/10.1016/j. ijbiomac.2018.11.079. PMid:30447375.

Yang, Z., Xu, J., Fu, Q., Fu, X., Shu, T., Bi, Y., \& Song, B. (2013). Antitumor activity of a polysaccharide from Pleurotus eryngii on mice bearing renal cancer. Carbohydrate Polymers, 95(2), 615-620. http://dx.doi. org/10.1016/j.carbpol.2013.03.024. PMid:23648020.

Zhang, A. Q., Zhang, Y., Yang, J. H., \& Sun, P. L. (2013). Structural elucidation of a novel heteropolysaccharide from the fruiting bodies of Pleurotus eryngii. Carbohydrate Polymers, 92(2), 2239-2244. http://dx.doi.org/10.1016/j.carbpol.2012.11.069. PMid:23399283.

Zhang, C., Li, S. S., Zhang, J. J., Hu, C. L., Che, G., Zhou, M., \& Jia, L. (2016). Antioxidant and hepatoprotective activities of intracellular polysaccharide from Pleurotus eryngii SI-04. International Journal of Biological Macromolecules, 91, 568-577. http://dx.doi.org/10.1016/j. ijbiomac.2016.05.104. PMid:27259648.

Zhang, C., Zhang, L., Liu, H., Zhang, J., Hu, C., \& Jia, L. (2018). Antioxidation, anti-hyperglycaemia and renoprotective effects of extracellular polysaccharides from Pleurotus eryngii SI-04. International Journal of Biological Macromolecules, 111, 219-228. http://dx.doi.org/10.1016/j.ijbiomac.2018.01.009. PMid:29309869.

Zhang, Y. Q., Geng, W., Shen, Y. Q., Wang, Y. L., \& Dai, Y. C. (2014). Edible mushroom cultivation for food security and rural development in China: bio-innovation, technological dissemination and marketing. Sustainability, 6(5), 2961-2973. http://dx.doi.org/10.3390/su6052961.

Zhao, Y. M., Yang, J. M., Liu, Y. H., Zhao, M., \& Wang, J. (2018). Ultrasound assisted extraction of polysaccharides from Lentinus edodes and its anti-hepatitis B activity in vitro. International Journal of Biological Macromolecules, 107B(Pt B), 2217-2223. http://dx.doi. org/10.1016/j.ijbiomac.2017.10.100. PMid:29051096.

Zheng, H. G., Chen, J. C., \& Ahmad, I. (2018). Preservation of King Oyster Mushroom by the use of different fermentation processes. Journal of Food Processing and Preservation, 42(1), e13396. http:// dx.doi.org/10.1111/jfpp.13396.

Zheng, H., Gao, J., Man, S., Zhang, J., Jin, Z., \& Gao, W. (2019). The protective effects of Aquilariae Lignum Resinatum extract on 5-Fuorouracil-induced intestinal mucositis in mice. Phytomedicine, 54, 308-317. http://dx.doi.org/10.1016/j.phymed.2018.07.006. PMid:30396718. 